Vol 11, Issue 3, 2018

\title{
POTENCY OF CHIVES (ALLIUM SCHOENOPRASUM L.) LEAVES INFUSE AS INHIBITOR CALCIUM LITHOGENESIS ON URINARY TRACT
}

\author{
SITI MORIN SINAGA*, IKSEN IKSEN, GINDA HARO, SELVY WARDHANY \\ Department of Pharmaceutical Chemistry, Faculty of Pharmacy, Universitas Sumatera Utara, Medan 20155, Indonesia. \\ Email: Sitimorinsinaga28@gmail.com
}

Received: 01 October 2017, Revised and Accepted: 25 November 2017

\section{ABSTRACT}

Objective: This study examined the antilithogenesis activity by in vitro and histopathologic study from the infuse solution of chives leaves powder.

Methods: The study begins with standard phytochemical screening on the powder of chives leaves. For performing in vitro antilithogenesis activity, atomic absorption spectrophotometry method was adopted to measure the dissolved calcium level. Histopathologic study was using animal models.

Result: Phytochemical screening of chives leaves powder has a lot of phytochemical constituents. In vitro assay showed that chives infuse can dissolve the human calcium stone ( $47.7 \%$ for $12.5 \%$ concentration of chives leaves infuse). The histopathologic study showed that chives leaves can be used to treat the calcium lithogenesis.

Conclusion: This experiment provides evidence that chives leaves have highlighted the potential efficacy for the treatment of calcium lithogenesis.

Keywords: Chives, Calcium oxalate, Lithogenesis, Infuse, Urinary.

(C) 2018 The Authors. Published by Innovare Academic Sciences Pvt Ltd. This is an open access article under the CC BY license (http://creativecommons. org/licenses/by/4. 0/) DOI: http://dx.doi.org/10.22159/ajpcr.2018.v11i3.22851

\section{INTRODUCTION}

The problems related with kidney are the major problem for human beings. The major functions of the kidney are balancing of electrolytes and regulation of water, production of erythrocytes, regulating the acidbase balance, regulation of blood calcium level, and involve the process of gluconeogenesis [1-3]. There will be many diseases which can affect the kidney function. Urolithiasis is one of the most painful ailments of the urinary tract disorder. In industrialized countries, approximately $10-12 \%$ of the population will develop kidney stones [4]. With a prevalence of $>10 \%$ and an expected recurrence rate of $\sim 50 \%$ stone disease has an important effect on the health-care system [5]. The most common type of stone contains calcium in combination with oxalate or phosphate [6].

Invasive procedures for the treatment of urinary calculi may cause serious complications and they also impose a great load of costs to the health-care system [7]. Using of herbal plants for the calcium lithogenesis is the best method in the traditional medicine. Because when we use the chemical compounds may induce the side effects for many organs of our body. However, plants are having a lot of phytochemicals, which heal the kidney damages without the side effects [3].

Chives (Allium schoenoprasum L.) is one of the important medicinal plants in Indonesia coming under the family of Liliaceae [8]. Chives contains a lot of phenolic compounds such as gallic acid, coumaric acid, ferulic acid, and rutin. Chives also contained a lot of potassium around $2960 \mathrm{mg} / 100 \mathrm{~g}$ [9]. The biomedical application of chives is very bulky one because it plays a very good role in various health problems such as treatment of vaginal discharge, constipation, infection, speed up the blood flow, antioxidants, breast cancer, and antihypertensive [10-13].

Previous research using the atomic absorption spectrophotometry showed that calcium levels will increase in kidney induced by ethylene glycol [14]. In vitro study using calcium oxalate powder showed that chives leaves effect can dissolve the calcium oxalate [15]. In this present investigation study of anticalcium lithogenesis activity of chives leaves infuse is carried out using real calcium stone from human to test the in vitro solubility in chives leaves infuse. The histopathology of kidney tissue from rats will be investigated by seeing the effect of chives leaves infuse on the damaged kidney tissue.

\section{METHODS}

\section{Plant material preparation}

A. schoenoprasum L. (chives) plant was collected from Pantai Labu region of North Sumatera, Indonesia, in February 2017. The plant sample was identified and authenticated by the Herbarium Medanense of University of Sumatera, Medan, Indonesia (No: 928/MEDA/2017).

\section{Preparation of infuse solution}

After authentication, A. schoenoprasum L. (chives) was collected and the leaf was separated carefully, washed thoroughly, and then dried it in oven. After drying, the leaves of A. schoenoprasum L.(chives) were ground using a mechanical blender into a powder. The infusion solution was made using dried chives leaves powder. Variation concentration of dried chives leaves infuse was made in $7.5 \%, 10 \%$, and $12.5 \%(\mathrm{w} / \mathrm{v})$. The doses used were in accordance with the Indonesian pharmacopoeia $4^{\text {th }}$ edition [16].

\section{Preliminary phytochemical screening}

Phytochemical screening carried out on A. schoenoprasum L. (chives) leaves powder included examing the chemical metabolites constituent of alkaloids, flavonoids, glycosides, saponins, tannins, triterpenoids, and steroids [17-19].

In vitro study using human calcium stone

In vitro study was conducted according to Iksen et al. In this study, samples were divided into three variations concentration of chives leaves powder $(7.5 \%, 10 \%$, and $12.5 \%)$. Each $100 \mathrm{~mL}$ of infuse from each group will be incubated with $100 \mathrm{mg}$ human calcium stone at $37^{\circ} \mathrm{C}$ for $4 \mathrm{~h}$. The human calcium stone collected from nephrolithiasis patients in Permata Bunda Hospital, Medan, Indonesia. After $4 \mathrm{~h}$, the solution of chives leaves powder will be measured using atomic 
absorption spectrophotometry at a wavelength of $422.7 \mathrm{~nm}$ to check the solubility of calcium.

\section{Preparation of calcium calibration curve}

A total of $10 \mathrm{~mL}$ of $1000 \mathrm{ppm}$ calcium (the mother liquor) were added to a $100 \mathrm{~mL}$ volumetric flask and then added aquabidest right to mark boundaries, the obtained raw potassium $100 \mathrm{ug} / \mathrm{mL}$. Each of $1 \mathrm{~mL}, 2 \mathrm{~mL}$, $3 \mathrm{~mL}, 4 \mathrm{~mL}$, and $5 \mathrm{~mL}$ pipetted calcium standard solution $100 \mathrm{ug} / \mathrm{mL}$ in a $50 \mathrm{~mL}$ volumetric flask to obtain a successive concentration of $1 \mathrm{ppm}$; 2 ppm; 3 ppm; 4 ppm; and 5 ppm and measured at a wavelength of $422.7 \mathrm{~nm}$ with an air-acetylene flame type using atomic absorption spectrophotometry.

\section{Destruction of samples}

$100 \mathrm{~mL}$ for each infuse solution was added by $10 \mathrm{~mL}$ nitric acid $65 \%$ and heat on a hot plate until the infuse solution become transpicuous.

\section{Measurement of dissolved calcium from calcium stone}

The sample solution that has been prepared with the absorbance measured using flame atomic absorption spectrophotometry at a wavelength $422.7 \mathrm{~nm}$ for calcium. Absorbance values obtained should be within the range of the calibration curve of calcium standard solution. Levels of calcium were calculated based on the regression equation of the calibration curve [15].

\section{Experimental design for histological assay}

For inhibiting calcium lithogenesis studies, adult male Wistar albino rats weighing around 170-180 g were selected. The animals were acclimatized to standard laboratory conditions and maintained for $12 \mathrm{~h}$ light and dark cycle. They were provided with regular rat chow and drinking water ad libitum. Our Institutional Animal Research Ethics Committees Approval No: 697/KEPH-FMIPA/2016.

In this study, animals were divided into five groups, each with five rats. The Group I act as normal group. Group II act as calculi control negative where animals received $0.75 \%$ ethylene glycol with $2 \%$ ammonium chloride in drinking water for 20 days. Group III animals received $0.75 \%$ ethylene glycol with $2 \%$ ammonium chloride in drinking water along with Batugin Elixir ${ }^{\circledR}$ from the $1^{\text {st }}$ day till the $10^{\text {th }}$ day. Rats in Group IV, $\mathrm{V}$, and VI were treated, respectively, with dried chives leaves infuse solution (doses: $7.5 \%, 10 \%$, and $12.5 \%$ ) from day 11 till the last day.

\section{Collection and analysis of tissue for histological assays}

After the last time of animal treatment, animals were anesthetized and killed. The kidneys were immediately excised and washed in ice cold PBS solution. Then, the kidneys were fixed in $10 \%$ buffered formalin. The stages of preparing histopathologic preparations consist of fixation, dehydration, clearing, embedding, blocking, sectioning, staining, and covering. The $5 \mu \mathrm{m}$ thick sections were stained through hemotoxylineosin solution and examined by light microscopy.

\section{RESULTS}

\section{Phytochemical screening}

Screening results of chives leaves powder showed on Table 1. which mean that chives leaves powder has different chemical compound.

\section{Calibration curve of calcium}

Fig. 1 showed that the correlation coefficient obtained can be accepted as the appropriate requirements for the correlation coefficient which should not smaller than 0.995 [15].

\section{In vitro result of dissolved calcium}

The dissolved calcium level from human calcium stone was investigated using atomic absorption spectrophotometry. Table 2 summarizes the result from in vitro dissolved calcium level.

\section{Histopathologic studies}

The result of histopathologic studies showed that the treatment group (Group IV-VI) showed similar characters in normal group (Figs. 2-4).
The crystal of calcium oxalate in negative control group is shown by circled area.

Table 1: Phytochemical screening result of chives leaves powder

\begin{tabular}{lll}
\hline No & Screening & Chives leaves powder \\
\hline 1 & Alkaloids & + \\
2 & Flavonoids & + \\
3 & Glycosides & + \\
4 & Saponins & + \\
5 & Tannins & + \\
6 & Triterpenoid/steroids & + \\
\hline
\end{tabular}

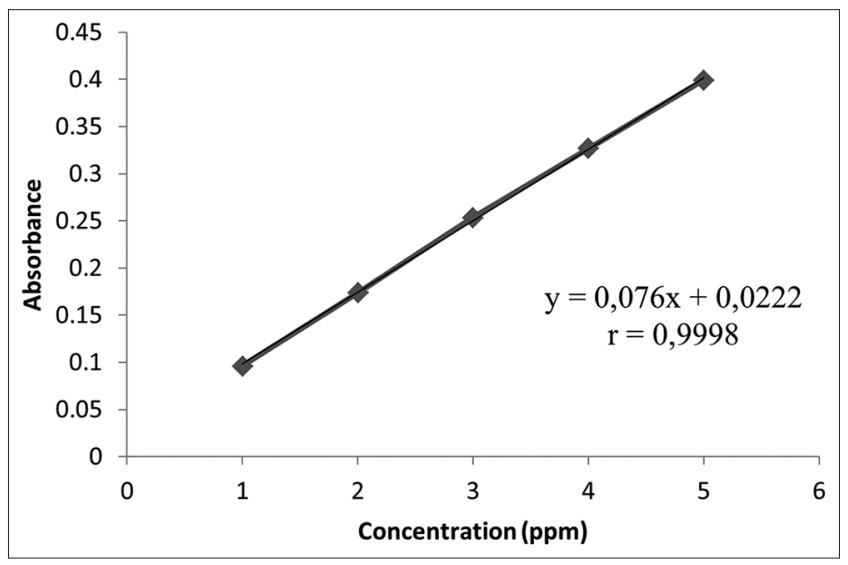

Fig. 1: Calibration curve of calcium

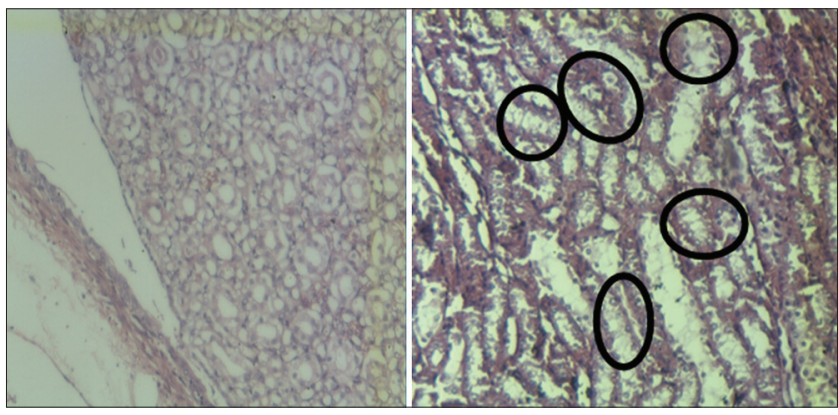

Fig. 2: The histopathology of kidney tissue in normal and negative control group

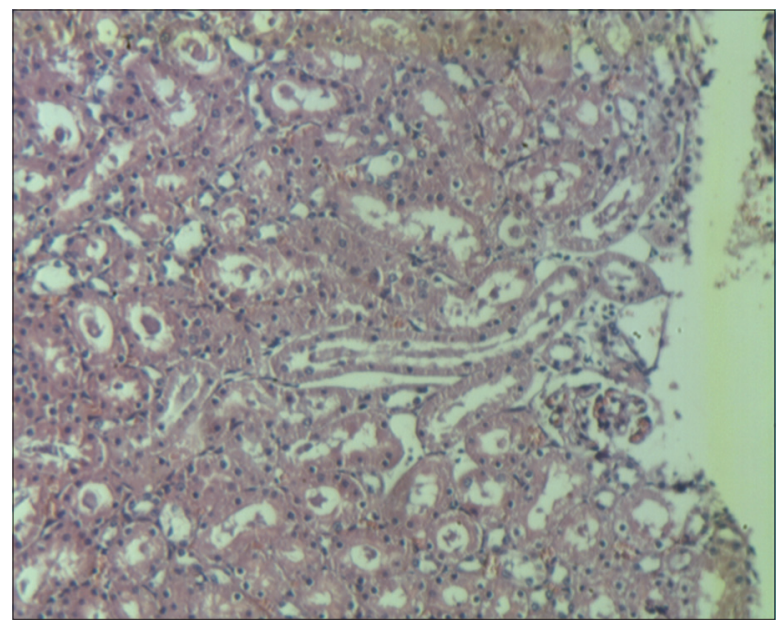

Fig. 3: The histopathology of kidney tissue in negative control group 
Table 2: Percentage of dissolved calcium from human calcium stone

\begin{tabular}{llll}
\hline No & Chives leaves power infuse solution $(\%)$ & Dissolved calcium level $(\boldsymbol{\mu g} / \mathbf{m L})$ & Percentage of dissolved calcium \\
\hline 1 & 7.5 & 33.7986 & 47.70 \\
2 & 10 & 17.5005 & 18.92 \\
3 & 12.5 & 46.3024 & 40.09 \\
\hline
\end{tabular}

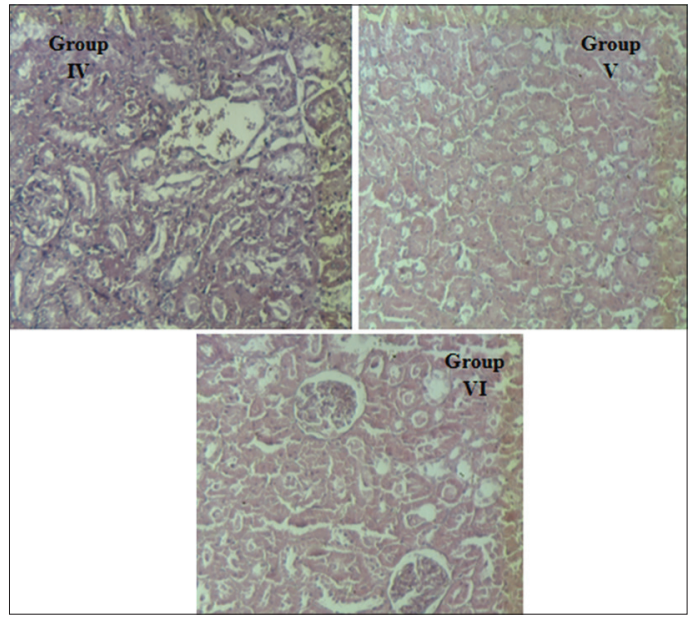

Fig. 4: The histopathology of the kidney tissue for Group IV-VI

\section{DISCUSSION}

According to our research, chives leaves infuse has a preventive effect on inhibit calcium lithogenesis, especially on calcium oxalate calculi formation in the kidney of rats. From the in vitro study results, it is observed that all concentrations of chives leaves powder infuse can dissolve the calcium oxalate stone. The best concentration observed from $7.5 \% \mathrm{w} / \mathrm{v}$ which produced the highest dissolution of calcium oxalate stones comparison to other concentration. Chives leaves infuse has a disruptive effect on calcium oxalate crystals formed by the final metabolic yield of ethylene glycol. In Fig. 2, no any calcium oxalate or other pathological defects were found in the different segments of the kidney tissue of the rats in Group I (control positive group).

On the other groups, many calcium oxalate crystal deposits were found in the Group II (negative control group). These calcium oxalate crystals can be found due to the effect of ethylene glycol induction effect. Metabolites of ethylene glycol such as glycolaldehyde, glycolate, and oxalate can induce tissue damage. The biochemical mechanisms for this process are related to an increase in the urinary concentration of oxalate [18]. Evidence from previous studies indicated that in response to 10 days period of ethylene glycol $(0.75 \% \mathrm{v} / \mathrm{v})$ and ammonium chloride $(2 \% \mathrm{w} / \mathrm{v})$ administration, male albino rats form renal calculi which can be shown by the increased calcium level in kidney [14]. The crystals of calcium oxalate in negative control group are shown in Fig. 2.

According to the histopathologic studies, the kidney tissue in Group III (positive control), Group IV-VI showed characters similar in normal control group. This can happen due to the effect of potassium and flavonoids in chives leaves infuse. Potassium can destroy the calcium stone according to the principle of Volta's row, while flavonoids can form complexes with calculi forming compounds and make it become soluble $[14,15]$. The other research investigation also said that the effect of inhibiting calcium lithogenesis is from the antioxidant effect of the flavonoids. It seems that flavonoids in chive could play an antioxidant role against oxidative stress that is induced by the ethylene glycol [20-25]. The histopathology of the kidney tissue for Group III-V is shown in Fig. 4.

\section{CONCLUSIONS}

The presented data indicate that chives leaves infuse has a good inhibitory calcium lithogenesis. Further studies are needed to prove the antiurolithiatic activity of chives leaves extract in other animal models.

\section{ACKNOWLEDGMENTS}

The authors wish to thank Suthinee Theerachetmongkol (Department of Internal Medicine, Faculty of Medicine Siriraj Hospital, Mahidol University) for helpful support in this project research

\section{AUTHORS CONTRIBUTION}

All the author have contributed equally.

\section{CONFLICTS OF INTERESTS}

Declared none.

\section{REFERENCES}

1. Sodimbaku V, Pujari L. Urolithiasis-an updated reviewe over genetics, pathophysiology and its cliical management. Int J Pham Pham Sci 2014;6:23-31.

2. Suryavanshi MV, Jadha SD, Gune RP, Bhatia MS, Shouche YS. HPLC analysis of human urine for oxalate content. Int J Pham Pham Sci 2016;8:54-9.

3. Ramesh K, Manohar S, Rajeskumar S. Nephroprotective activity of ethanolic extract of Orthosiphon stamineus leaves on ethylene glycol induced urolithiasis in albino rats. Int J PharmTech Res 2014;6:403-8.

4. Winston D. Herbal and nutritional treatment of kidney stones. J Am Herbalists Guild 2011;10:61-9.

5. Saha S, Ramtej JV. Bergenia ciliata extract prevent ethylene glycol induced histopathological changes in the kidney. Acta Pol Pharm Drug Res 2010;68:711-5.

6. Taylor CS, Goyal A. Isolation of phytoconstituents and in vitro anthilithiatic by titrimetic method, antioxidant activity by 1,1-diphenyl2-picryl hydraziyl scavenging assay method of alcoholic roots and rhizomes extract of Hedychium coronarium J Koenig Plant species. Asian J Pharm Clin Res 2015;8:225-9.

7. Hadjzadeh MA, Mohammadian N, Rahmani Z, Rassouli FB. Effect of thymoquinone on ethylene glycol-induced kidney calculi in rats. Urol J 2008:5:149-55.

8. Iksen. The Effect of Chives (Allium schoenoprasum, L.) Leaves Infuse on the Calcium Salt Solubility Using in vitro and in vivo by Atomic Absorption Spectrophotometry. Thesis 2017, Faculty of Pharmacy, University of Sumatera Utara: 1-72.

9. Al-Snafi AE. Pharmacological effects of allium species grown in Iraq. Int J Pharm Health Care Res 2014;1:132-55.

10. Amalia L, Sukandar EY, Roesli RM, Sigit JI. The effect of ethanol extract of kucai (Allium schoenoprasum L.) bulbs on serum nitric oxide level in male wistar rats. Int J Pharm 2008;4:487-93.

11. Jalkumar B, Jasmine R. A review of a few medicinal plants possessing anticancer activity against human breast cancer. Int J PharmTech Res 2016;9:333-65.

12. Parvu AE, Parvu M, Vlase L, Miclea P, Mot AC, Dumitrescu RS. Antiinflammatory effects of Allium schoenoprasum L. leaves. J Physiol Pharmacol 2014;65:309-15.

13. Sachinm UR, Priyanka RP, Sagar RM. Use of natural antioxidants to scavenge free radicals: A major cause of diseases. Int J PharmTech Res 2010;2:1074-81

14. Haro G, Sinaga SM, Iksen I, Nerdy N, Theerachetmongkol S. Protective effects of chives leaves (Allium schoenoprasum L) infusion against ethylene glycol and ammonium chloride induced nephrolithiasis in rats. J Appl Pharm Sci 2017;7:222-5.

15. Iksen I, Haro G, Sinaga SM. In vitro test of chive leaves infuse (Allium schoenoprasum, L) on calcium oxalate solubility using atomic 
absorption specthrophotometry. Int J ChemTech Res 2017;10:99-2.

16. Indonesia's Ministry of Health. Indonesia Pharmacopoeia. $4^{\text {th }}$ ed. Jakarta: Indonesia's Ministry of Health;

17. Depkes RI. Materia Medika. Vol. 6. Indones: Ditjen POM; 1995. p. 297-307.

18. Farnsworth NR. Biologycal and phytochemical screening of plants. J Pharm Sci 1996;55:225-76

19. Harbone JB. Metode Fitokimia. Vol. 2. Bandung: ITB 1987. p. 49

20. Velpandian V, Rajaprehidha SS, Banumathi V, Anbu J, Anjana A. Effect of vediyuppu cheyaneer in ethylene glycol induced hyperoxaluria model in rats. Int J Life Sci Pharm Res 2012;2:63-7.

21. Shekha MS, Ismail TF, Aziz FM. Anti-urolithiatic and anti-oxidant effects of fenugreek on ethylene glycol-induced kidney calculi in rats.
Jordan J Biol Sci 2015;8:159-63.

22. Deepika A, Minu S, Singla SK. The role of natural antioxidants as potential therapeutic agent in nephrolithiasis. Asian J Pharm Clin Res 2013;6:48-53.

23. Lee HJ, Jeong SJ, Park MN, Linnes M, Han HJ, Kim JH, et al. Gallotannin suppresses calcium oxalate crystal binding and oxalate-induced oxidative stress in renal epithelial cells. Biol Pharm Bull 2012;35:539-44.

24. Antunes LM, Darin JD, Nde LB. Effects of the antioxidants curcumin or selenium on cisplatin-induced nephrotoxicity and lipid peroxidation in rats. Pharmacol Res 2001;43:145-50.

25. Sudhahar V, Veena CK, Varalakshmi P. Antiurolithic effect of lupeol and lupeol linoleate in experimental hyperoxaluria. J Nat Prod 2008;71:1509-12. 